Article

\title{
Spatial Analysis of the Distribution of Small Businesses in the Eastern Villages of Gilan Province with Emphasis on the Tourism Sector in Mountainous Regions
}

\author{
Mehdi Hajilo ${ }^{1, *}$ (1) Mojtaba Ghadiri Masoom ${ }^{1}$, Seyed Hassan Motiee Langroudi ${ }^{1}$, \\ Hassanali Faraji Sabokbar ${ }^{1}$ and Lori Pennington-Gray ${ }^{2}$ \\ 1 Department of Human Geography, Faculty of Geography, University of Tehran, Tehran 14178, Iran; \\ mghadiri@ut.ac.ir (M.G.M.); shmotiee@ut.ac.ir (S.H.M.L.); hfaraji@ut.ac.ir (H.F.S.) \\ 2 Tourism Crisis Management Institute, Department of Tourism, Recreation and Sport Management, \\ University of Florida, Gainesville, FL 32611, USA; penngray@hhp.ufl.edu \\ * Correspondence: mehdihajilo@ut.ac.ir; Tel.: +98-936-203-4285
}

Received: 29 August 2017; Accepted: 30 November 2017; Published: 4 December 2017

\begin{abstract}
The development of small businesses in rural areas as a key strategy for sustaining the population and improving the quality of life of villagers has always been a concern for many developed and developing countries. Some rural areas provide their villagers with favorable conditions for the development of businesses in order to enjoy the potential in the field of tourism. Sustainable development in these areas can be achieved with systematic attention and planning. In the present work, the spatial analysis of the distribution of small businesses in the eastern parts of Gilan Province was studied with an emphasis on tourism in mountainous regions. The study population consisted of all villages in the east part of Gilan Province, and the sample included all businesses officially supported by the Omid Entrepreneurship Fund. The research method was a descriptive analytic in which GIS software and the G statistic were used for the analysis of spatial correlation, clustering, hot and cold spots analysis and buffer zones. Finally, the results of the study showed that the spatial distribution of businesses in different economic sectors (agriculture, industry, services and tourism) were different between 2011 and 2016 in the way the cluster pattern was formed in agricultural and service activities. A cluster pattern cannot be considered in the tourism and industrial activities, but there is a random (point) pattern; in this regard, the results indicate the importance of the factor of distance between the village and the city center in the distribution of tourism businesses. In addition, the highest levels of support for businesses were in the agricultural and services sectors, while the lowest support was in industry and tourism. Finally, the results showed that the distribution of businesses in all activities was much higher in the plains and valleys as compared to the mountainous and hill areas.
\end{abstract}

Keywords: spatial analysis; small businesses; tourism; rural areas

\section{Introduction}

Over the past twenty years, tourism has expanded and been recognized as the largest industry in the world [1]. Certainly, in both developed and developing countries, tourism is often a type of service to stimulate regional economic activities [2]. Rural tourism is linked to many other tourism patterns, but its distinguishing characteristic is its setting [3]. Rural tourism typically involves recreational activities in rural areas that arose due to urbanization and industrialization in the 19th century [4]. In recent years, its development and prosperity as one of the most important strategies for rural 
development has attracted the attention of scholars, especially rural experts, and is considered a strategy for local and regional development [5].

Tourism development in recent times has shown that tourism is an innovative tool for the revival of rural areas in developing countries [6]. In other words, the growth and development of tourism can lead to increased employment, especially business development for the local people. Considering the economic and social conditions and the potential of each region, the development of tourism can create the basis for employment and entrepreneurship and provide areas of growth and development for that region [7]. Rural tourism also enables privately run, small businesses to emerge as an economic development engine. It can be one of the main strategies for solving rural problems, diversifying the economy and making optimal use of the resources of the country's villages [8].

A systematic and clustered distribution and development strategy is one of the more successful strategies for organizing small and medium-sized businesses, which has emerged a major role in regional development in different countries and has helped the local population at the micro level over the past three decades [9]. In fact, the systematic and clustered development of businesses, especially in the tourism sector as a socio-economic system, has been based on the two foundations of the empowerment and sustainability of stakeholders and local people [10,11]. Huybers and Bennet [12] have studied a systematic and clustered development approach and distribution of the tourism industry and suggested a framework for tourism development. Rosenfield [13] explored the strategy for systematic and centralized businesses in rural communities where the economic development of community combined with the collaborative network contributed to improving the lives of local people.

Thus, research suggests that a systematic, regular and clustered distribution of businesses, especially those in the tourism sector could lead to greater economic efficiencies within the rural communities. Such as strategy can result in people starting new businesses either within or outside of their primary sector. For example, a farmer can open a "U pick" business marketed at tourists. Such strategies enable small businesses to spread revenues over a seasonal business and create new revenue streams that can improve household economic livelihoods.

Unfortunately, knowledge of the opportunities to branch out into other economic service sectors is usually sparse. Most businesses are not aware of how to engage in such a venture. Understanding how to attract local's participation in diversification strategies is typically the role of the government. Creating sustainable employment and businesses for the people is one strategy of investment that typically yields profitable outcomes. Governments can invest in clusters of businesses that support specific sectors-such as tourism. Planning, training, financial aid, and investment in infrastructure are all ways the government can help to foster business diversification and business clusters in rural communities.

The mountainous areas of eastern Gilan annually attract tourists from a variety of regions both within Iran as well as outside of Iran. Tourists are drawn to the area due to its natural beauty, including forested mountains, natural waterfalls and very suitable climatic conditions. Most of the time, however, there is a large amount of migration into the area of tourism workers, which tends to displace the rural population. The present study attempted to examine the spatial distribution of micro and small businesses in these regions, in order to understand the economic diversification of the region. The findings from the study can be used to aid the government in planning for business diversification and ultimately economic viability and prosperity for the native rural villagers. The main question of the present research is as follows:

Is the spatial distribution of small businesses in mountainous villages structured and systematic to improve the life of the villagers, especially the tourism sector?

\section{Study Area}

The study area consists of the total rural areas of the eastern cities of Gilan Province, which includes the five cities of Rudsar, Lahijan, Amlash, Langrood and Siahkal, the coordinates of each of which are as follows. Rudsar is located on the southern coast of the Caspian Sea with geographical 
coordinates of $50^{\circ} 6^{\prime}-50^{\circ} 36^{\prime}$ east longitude and $36^{\circ} 38^{\prime}-37^{\circ} 12^{\prime}$ north latitude at a height of $22 \mathrm{~m}$ in the province of Gilan [14]. The city of Langrud is located in the eastern part of the province of Gilan; the city is bounded by the Caspian Sea to the north, by the city of Siahkal to the south, by the city of Lahijan to the west and by the cities of Rudsar and Amlash to the east [15]. The city of Siahkal is located in the east of Gilan Province; it was isolated in 1997 from the city of Lahijan and became an independent city. This city is bounded by Lahijan in the north and northeast, by Rudbar to the northwest, by Langroud and Amlash to the east and by Rudsar to the southeast [16]. The city of Amlash is a new city, which is located in the east of Gilan Province; it is bounded by the city of Rudsar to the north and east, by Siahkal to the south and by Langrud to the northwest [17]. The city of Lahijan is bounded by the Caspian Sea to the north, by Langrood to the east, by Deilaman to the south, by Siahkal to the southwest and by Astaneh Ashrafiyeh to the west (Figure 1).

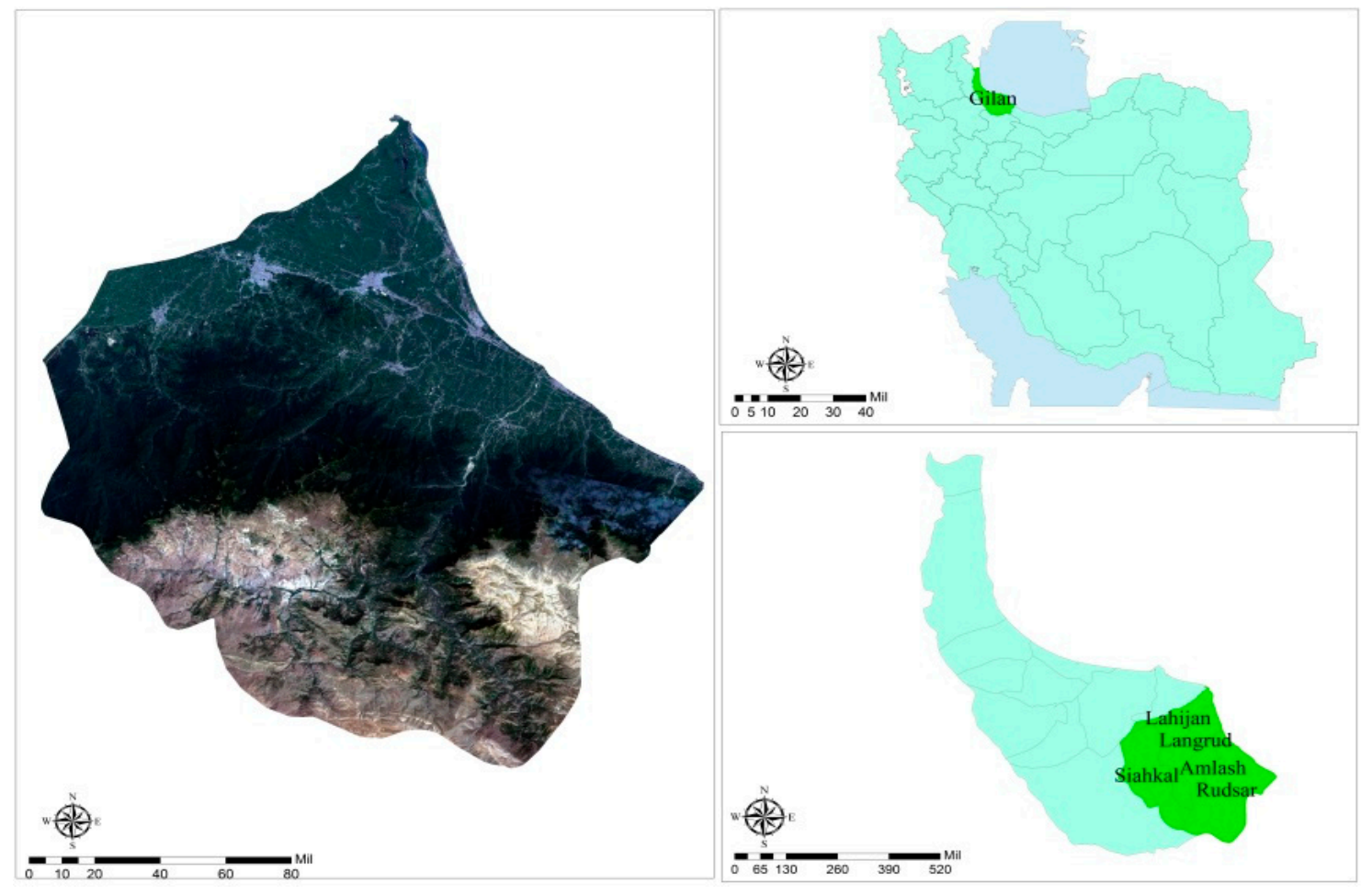

Figure 1. Map of the study area.

Economic and tourism situation in the study area:

The area under study is largely dependent on agriculture, livestock, and forestry for the supply of raw materials because of its thriving agriculture and massive forests. The province's major industries include food, spinning, weaving, wood and paper. Due to the abundance of forests in this area, the wood and paper industry is one of the most important industries of the province and even the country. Handicrafts such as making baskets, mattresses, and the production of wooden items are other sources of money and income. The study area has a great potential for tourism development. The diversity of geographic conditions attracts and retains tourists. In terms of topography, the factor of elevation divides the study area into shores, plains, foothills and mountains. The climate in the coasts, plains, foothills and mountains, the flow of rivers across the province from west to east and south to north of the region, and the beaches throughout the province all allow for the possibility of exploitation for tourists. Additionally, forest and pasture vegetation and the distribution of rural, nomadic and urban settlements, as well as other ecotourism and cultural tourism attractions, comprise the capacities for tourism that have made the context for development at the local, national and even international level [18]. 


\section{Literature Review}

Rural tourism is a shift from rural general economics to a new specialized economy. This is not a linear process, but includes experiments, learning processes, new capabilities, new policies, modifications and updates [19]. In Iran, the theme of rural tourism has been considered as one of the branches of the tourism sector since the early 1990s, but despite the growing trend of rural tourism research and the emphasis of scholars on this subject, this issue still does not have a proper legal status in the country's development planning process and has not been considered as an appropriate strategy in the framework of an economic approach to help develop rural areas [20]. Though 20 million tourists have been predicted for the whole country in the 2025 vision document [21] and despite the privileged rank of Iran in enjoying tourist attractions, Iran's share of world tourist income has been less than one percent [22]. On the other hand, small businesses around the world are recognized as key players in economic development, job creation, innovation, income generation and public health, as well as the national and international welfare of the economy [23-25], as the undeniable importance of these businesses in many international organizations around the world and in national organizations within countries has provided various types of support for the development of these businesses [26]. Meanwhile, small and medium-sized businesses are dominant in number compared to other businesses and are a distinct key, especially in the future of the tourism industry [27]. For example, in Finland, 90 percent of the tourism businesses have been classified as micro and small businesses [28], so experience shows that the implementation of sustainability plans has encountered problems, especially problems for small businesses, which were dominated by sectors such as tourism [29]. The variability of business conditions and its geographic complexity often indicate the sources of risk that require long-term management to reduce or eliminate their effects on the business process [30]. Given that businesses are increasingly exposed to dissolution, it is almost impossible to anticipate their nature, time and development, so a preventive mechanism equipped with a decision support framework is needed to protect them against the consequences of disastrous events [31].

In the rural tourism sector, small businesses take the form of family businesses and community-based tourism, all of which may have significant benefits in empowering rural residents in developing countries; in the meantime, studies such as [32,33] have emphasized strengthening the main source of funding for tourism-related micro and small businesses, which are usually created with financial and personal resources of business owners instead of official budgets such as bank loans. Therefore, it is very important to examine barriers to the development of tourism-related businesses and to improve the business environment in this area for the further development of tourism [34].

\section{Small Businesses}

Creating and developing small businesses is one of the strategies that has been taken into consideration by the governments of different countries in recent years. In this strategy, the employer, who is an entrepreneur in many cases, launches a business in his/her own environment using the available facilities, and creates jobs for himself/herself and sometimes others [35]. From the economic point of view, small businesses are a tool for economic and social growth and can be effective at reducing unemployment by creating new employment opportunities [36].

These types of businesses are defined as businesses that mainly belong to the private sector; the number of employees is limited and the sale of its products is low. The concept of small in this definition is variable and depends on the type of activity or the country under consideration. The Georgia Institute of Technology has achieved fifty definitions in its review of 75 countries [37]. This number varies from less than eight in the United States [38] to up to 500 workers in China [39]. In Germany, businesses with less than 10 employees are considered to be small, and in Iran, businesses with nine or fewer employees are considered micro and small businesses. Of course, in the definition of small businesses, in addition to the number of employees, there are other indicators such as annual sales (turnover), the value of assets and net profit (balance sheet) and especially the volume of investment that are very important [40]. In fact, in addition to building employment in the development process, 
these types of businesses can build capacity and allow entry into global markets [41]. Some of these businesses are in rural areas and become the most important element of rural economics by creating jobs and reducing unemployment and increasing income and productivity [42]. In the definition of rural businesses, three criteria and parameters can be considered: first, providing villagers with services; second, being located in a rural area; third, supplying and selling rural products and services, including foodstuffs and other natural products, handicrafts, recreational activities or environmental goods [43]. An important part of these businesses is rural non-agricultural enterprises, which create income sources for villagers by creating new sources of income outside the farm [44].

Research subject sustainability perspectives:

Small and medium-sized businesses are the main actors in global industry. For the first time in 1990, Michael Porter [45], with the publication of cluster theory, acknowledged the success of small and medium-sized businesses through their organization, distribution and management and introduced the lack of distribution of powerful clusters in these countries as the main reason for the weaknesses of competitiveness. In the meantime, tourism as a complex economic activity has had numerous links with a wide range of sectors and economic activities, thus having multiple positive impacts and strong potential as a catalyst for economic development [46]. In fact, tourism can play an important role in moving towards high growth, creating employment and generating positive tension that directly and indirectly affect other economic activities [47].

At the local level, tourism brings opportunities for employment and income, regional stimulation and the development of local economies, which often provide a unique chance for many small and remote locations that experience limited development options. Thus, according to Ólafsdóttir and Runnström [48], decision-makers directly need planning tools to guide tourism development with regards to environmental, cultural and economic sustainability. Tourism is managed for sustainability when a long-term recovery in the local and infrastructural economy is provided.

According to Andriotis [49], this industry has been probably the only growing industry for marginal geographical areas and remote rural areas, and according to Irvine and Anderson [50], it has potential to fight the economic crisis and prevent population decline in remote areas. Meanwhile, although the spatial distribution aspects of tourism are often neglected in tourism development policy [51], their importance in sustainable tourism development is now recognized by governments and tourism development planners. In this regard, GIS has a very high potential to achieve better insight into the structure and function of the tourism system in a particular region, to plan for the development of tourism in a sustainable direction, or to control and monitor the effects of previous programs [52,53].

The spatial development of each region and attention to its past are related to the factors and events that have created the conditions of the environment over time [54]. This spatial distribution can reveal underlying patterns of various topics, and the clusters are being studied using the spatial distribution, which provides information about geographic roots and patterns of these topics [55]. These patterns can be better understood because the ordering and arrangement of point-wise combinations are of basic issues in the spatial analysis of phenomena from the locations of the points from their spatial construction process [56]. By using this spatial analysis, it is possible to establish a logical relationship between human population dispersion and environmental resources [57].

Research on entrepreneurship and business has been relatively understudied in tourism [58,59]. Generally, in the studies of entrepreneurship, typically lifestyles of entrepreneurs are referenced. However, there are some studies worth mentioning in this regard. In one study, a researcher identified the factors affecting the formation of small and medium-sized enterprises with a focus on rural tourism (case study: City of Tehran). The research methods were quantitative, using a questionnaire; the results showed that the highest motivation for tourists was from the rural areas of Kan and visiting natural attractions and places of pilgrimage, except the shrine of Davoud. Activities of tourism agencies such as entertainment centers, restaurants, residential services, shopping malls, tourist guides, selling 
livestock and agricultural products, transportation of tourists, selling crafts and local food supply in rural areas did not grow and develop significantly. From the viewpoint of the residents, some of the region's advantages in creating and developing a tourism business were the short distance from the City of Tehran and natural and pilgrimage attractions [60].

A researcher in another study examined the role of tourism in rural women's entrepreneurship development (Gourab Pas village of Fouman City). This study used a quantitative method. The results showed that only $11 \%$ of people earned money from the sale of handicrafts and renting rural homes to tourists. Therefore, it can be concluded that despite the potential natural and human contexts within this village, tourism has still not been able to play a significant role in employment, actualizing potential capabilities, improving the socio-economic status of the local people and promoting the entrepreneurship of women in this village [61].

Other research examined event tourism in the Russian regions. One study observed an opportunity for growth in small businesses. The research methodology was descriptive-analytic with a general evaluation method. Finally, the results showed that although event tourism is a challenging sector, it was an important strategy for the Russian economy, and the results also revealed what barriers should be broken down and what potential should be used to reach the desired Russian goal: the development of small and medium-sized businesses [62].

In a study entitled "The factors affecting the distribution of economic activities in the city of Isfahan", Farahmand et al. [63] determined the location of economic activities as one of the most important elements of the urban environment in the city. In this regard, the results showed that the existence of banks had an effect on the distribution of economic activities; in addition, the presence of specialists and environmental diversity have been stated as other important factors in the distribution of economic activity.

In a study on the spatial distribution of tourism development indicators using the TOPSIS model, Zangi Abadi et al. [64] conducted an evaluation and prioritization according to the indicators of tourism development (the extent of enjoyment of natural, historical, cultural, human-made attractions, hotels, etc.) at the four levels of well-equipped, equipped, medium and low-equipped. The results show two levels, in which Isfahan was located at the well-equipped level with a priority coefficient of $0.87 \%$, but other cities were at a low level.

Fong et al. [65] examined the spatial distribution of Chinese ethnic businesses in the suburbs, based on Toronto business data between 1995 and 1996, in which the determinants of the spatial distribution of ethnic businesses were studied based on the dimensions of human ecology, economic sociology and the organizational ecological viewpoint. The results showed that the distribution of suburban ethnic business is not related to most of the factors raised from the human ecological point of view; in contrast, the results indicate the coordination of these ethnic businesses with economic sociology and organizational ecology in understanding the spatial distribution of these businesses.

In a study on the spatial distribution of facilities and logistics in Andalusia, Sarrión-Gavilán [52] analyzed the flows of tourism using GIS and their effects by focusing on the provision of residence and local population size. The results showed that there was a permanent imbalance between coastal and inland areas in such a way that there was a high degree of concentration of the population in coastal areas. Furthermore, with the emphasis on its permanent inhabitants, tourism activities have caused pressure on some urban regions in mountainous areas with high quality landscape and environment. Though a kind of traditional tourism has dominated some parts of the West, the proper territory is concurrent with tourism distribution and low pressure on the environment and a very high quality in tourist destinations of coastal areas and sometimes in some rural areas.

Therefore, studying and investigating the research on this subject satisfies three gaps: (1) extends the literature to consider the distribution of large-scale businesses without the division of the small, medium or large businesses; (2) focuses on the distribution of businesses regardless of the type of economic activity (agriculture, industry, service); (3) focuses on the distribution of businesses by putting emphasis on metropolitan and regional scales; (4) focuses on the distribution of economic 
activities, with an emphasis on the industrial sector and the tourism sector. Therefore, the goal of the present study was to explore micro and small businesses in a small rural village in Iran, paying close attention to the share of different economic sectors in the rural areas in order to strengthen the economy. Particularly, the tourism sector will be examined in relation to other sectors, to determine if adjusting the volume of businesses and increasing diversity can aid in improving economic livelihoods for villagers.

\section{Materials and Methods}

This is an applied study by the objective and descriptive-analytical method. The present study is an assessment of spatial distribution of small businesses in mountainous villages in east Gilan. It studies whether the distribution has been structured and organized, or has failed to follow a specific pattern. The demographics of each of the cities and the number of mountainous villages are presented separately in Table 1.

Table 1. Demographic data of the study area separated by city.

\begin{tabular}{ccccc}
\hline Province & City & $\begin{array}{c}\text { Number of } \\
\text { Mountainous Villages }\end{array}$ & $\begin{array}{c}\text { Number of } \\
\text { Households }\end{array}$ & Population \\
\hline Gilan & Amlash & 61 & 2960 & 9020 \\
Gilan & Langrud & 104 & 4341 & 13,540 \\
Gilan & Lahijan & 63 & 4529 & 14,317 \\
Gilan & Siahkal & 133 & 5437 & 16,836 \\
Gilan & Rudsar & 185 & 5955 & 18,394 \\
\hline \multicolumn{6}{c}{ Total } & 546 & 23,222 & 72,107 \\
\hline
\end{tabular}

Small businesses in the sector of agriculture, service, industry and tourism were assessed. (It should be noted that economic activities can be divided into three categories of agriculture, industry and services; in other words, activities related to the tourism sector are considered as a subset of service activities.) In this regard, service activities have been thoroughly investigated in order to carefully assess the level of financial support, and those activities related to the tourism sector have been examined separately. Other activities of the service sector, which have no connection with tourism, were evaluated separately.

In addition, relative comparison of the mountainous areas with other areas in terms of business with emphasis on tourism businesses, comparison of the spatial distribution of tourism businesses with other types of businesses in terms of time and finance and the recognition of the dominant type of economic activities in areas with a different natural situation have been investigated.

It is worth mentioning that, to collect the required data, we used the data from the Omid Entrepreneurship Fund, which is a government sponsor for small rural businesses and has all of the business data (since, over the past few years, the Omid Entrepreneurship Fund, which presented various services with different names and purposes, and from the years 2006-2011, the information package on the financial support for businesses was only provided by a centralized system and was not on a city and village basis, there was general and unseparated information, but given that since 2011, the information was broken down based on each city and village in relation to all small businesses and their financial information in a separate system, according to the purpose of the research and its scale, which was at the village level, the data for 2011-2016 were analyzed separately). Finally, in order to analyze the spatial data and the importance of the distance factors in the distribution of tourism businesses, ArcGis, G statistics, spatial correlation analyses, clustering, and hot and cold spots analysis are used. The Multiple Ring Buffer tool (which is one of the adjacency measurement tools based on complications in GIS, in which buffer zones can be created around three geometric objects of point, line, and polygon, and which can determine which object is inside or outside of the complication or can be used to indicate the importance of the distance between the complications) was also used. 
Today, the Geographical Information System (GIS) is widely used as a valuable tool for management, analysis and presentation of various and great volumes of data, as well as different local planning activities; accordingly, it is necessary to use it for tourism planning and management [66]. In this regard, Dye and Shaw [67] emphasized that since tourism includes a wide variety of elements including facilities, activities, services and travel experiences, GIS software can be used effectively as a useful application in planning and management. It can also be used as a valuable tool for exploring specific issues related to tourism development, such as location, regional conditions, trends and changes, routing through locations and patterns related to resources.

\section{Hot Spot Analysis}

Hot spot analysis calculates the Getis-Ord Gi statistic for all the complications in the data. The calculated $\mathrm{Z}$ score indicates which part of the data is clustered into small and large values. In other words, if we have a set of weighted complications, this tool identifies the clusters of complications with high values (hot spots) and clusters with low values (cold spots) [68]. For a complication to be regarded as a hot spot and statistically meaningful, both it and its neighbor must be of great value. The local sum of the complication and its neighbors is compared relatively to the total sum of complications. When the local sum is greatly larger and more unexpected than the local sum and the difference is so large that it cannot be considered an accident in the result, the $\mathrm{Z}$ score will be obtained (Figure 2).

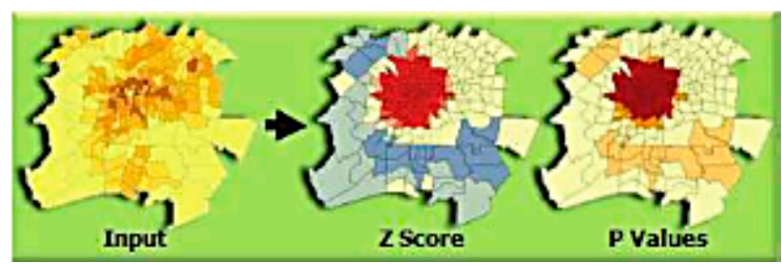

Figure 2. Input and output hot spot tools [68].

Cluster analysis is one of the most useful tools for displaying the statistical distribution of phenomena in space, with the assumption that we have several weighted geographic complications; this tool shows where the high or low quantities of these phenomena are distributed as clusters in space and, also, which complications are very different from the complications surrounding them (Figure 3).

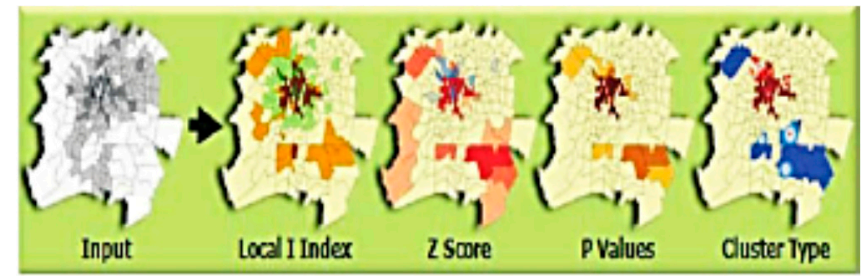

Figure 3. Schematic diagram of the input and output of cluster and non-cluster analysis [68].

\section{Results and Discussion}

The survey of the spatial distribution of businesses in different economic sectors (agriculture, industry, services and tourism) during 2011-2016:

Considering that economic activities are investigated in three groups: industrial, agricultural, and service, in the present study, those businesses that are related to the tourism sector have been considered as one separate sector and compared to other sectors. Accordingly, in the present study, economic activities in the four groups are examined.

As the results show (Figure 4), in relation to businesses related to the tourism sector, in the years between 2011 and 2016, 88 businesses were set up; most of them were in 2011 with 21 businesses, 
and the least of them were in 2014 with six businesses. The process of setting up businesses in the tourism sector has not been increasing during the aforementioned years; on the contrary, there has been a decreasing trend over these years, and as the results show, hot and cold spots have not been able to form in the businesses associated with the tourism sector; we cannot consider a model for these types of businesses in the region, because the points are scattered and completely heterogeneous, representing insignificance in relation to a particular pattern in the distribution of activities.

Because the process of distributing businesses is completely pointwise, it cannot be seen that several businesses related to the tourism sector are formed in each village at the same time. This kind of distribution solely involves the owner of the business or their family in this sector, not the majority of the village population, therefore, there can be no good economic advantage with this limited range of scope because the lack of tourism services and welfare facilities in these villages could result in inability to attract more tourists or, if they enter, they will have a very short stay in these areas.

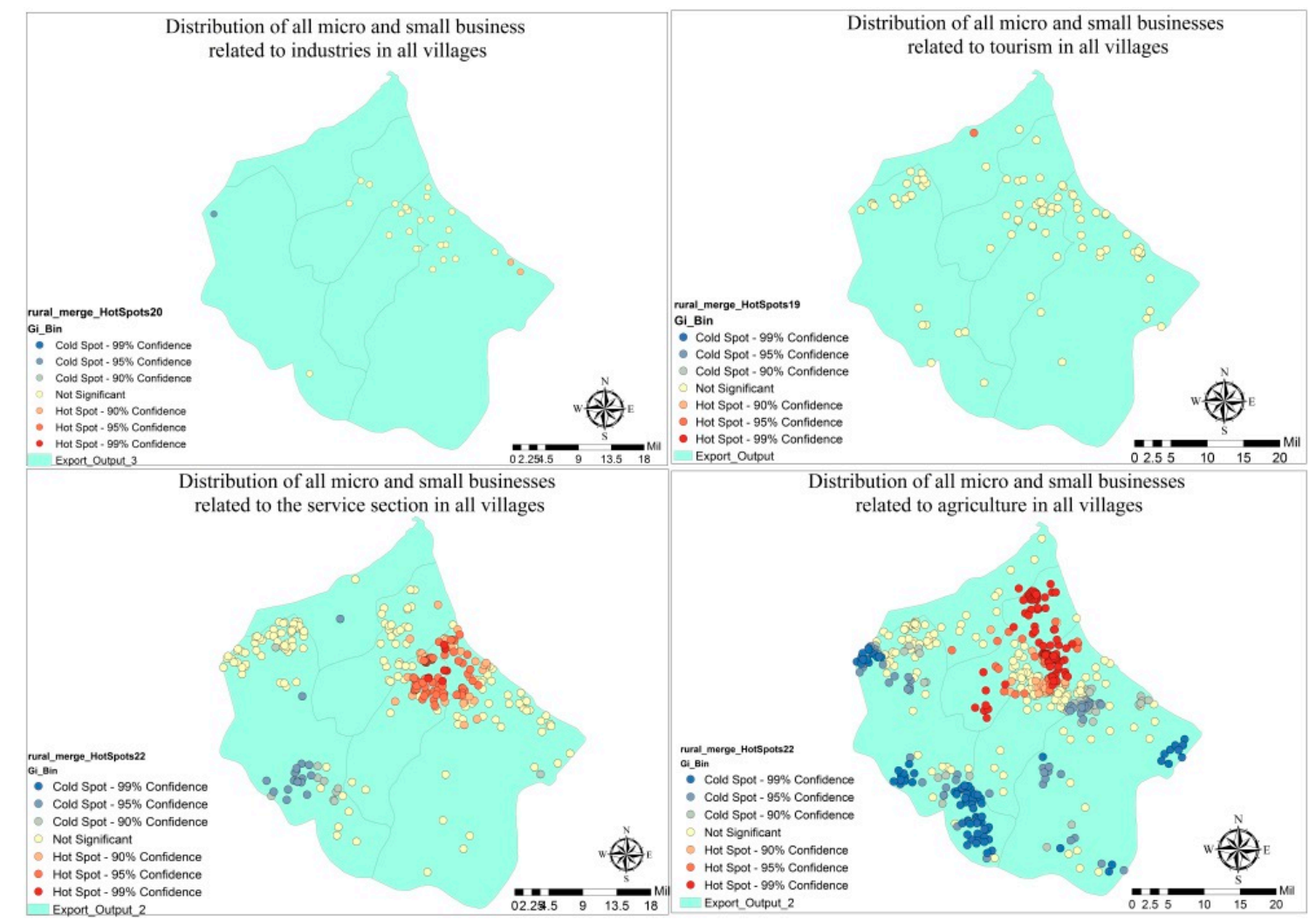

Figure 4. Spatial distribution of the four economic activities.

In relation to industry-related businesses, the results show that the total number of businesses in the years 2011-2016 was very limited (28 businesses), among which, the highest and lowest numbers were in 2011 and 2012 (two businesses), respectively. Of course, in the rest of the years, it has not been increasing, but decreasing; and similarly, the results show that the phenomenon of hot or cold spots has not formed for this activity, indicating the lack of a specific and coordinated distribution pattern associated with this kind of business.

In relation to the service sector businesses, the results showed that many businesses in the rural areas are part of the agricultural sector. However, the most important point is that during the period from 2011-2016, the spatial distribution of business related to this sector has not been associated with a regular and increasing trend. On the contrary, the trend has been decreasing in some years. For example, in 2011 and 2016, with the largest (79) and smallest (27) number of businesses startup rates, the trend has not been steady. In this regard, a hot spot was formed that is indicative of a 
cluster pattern with high values, meaning that in this area, aggregation and compaction of businesses can be seen with a confidence level of $90 \%$ and $95 \%$. On the contrary, a cold spot is formed, which shows that fewer businesses are concentrated there, so that it did not have the intensity of the hot spot cluster pattern.

Finally, in relation to agricultural-related businesses, the results showed that most of the businesses created during the period from 2011-2017 were agricultural, although these businesses went through a declining trend in 2012, 2014 and 2015 and an increasing trend in 2016. However, it should be noted that due to the plurality of this type of business in some areas, hot spots and cold spots were formed in some areas in relation to these types of businesses. In relation to hot spots, it indicates a cluster pattern distribution, showing a kind of aggregation and polarization in these areas, which can be observed in some areas with a confidence level of $90 \%$ and even some points with a cluster pattern of $99 \%$. In contrast, in some places, there has been the emergence of cold spots; in fact, these ranges indicate that less cluster businesses are formed, and there has never been a pattern in other areas.

Study of the status of financial support for the four activities (agriculture, industry, services and tourism) during 2011-2016:

As mentioned earlier, economic activities can be divided into the three categories of agriculture, industry and services; in other words, activities related to the tourism sector are considered as a subset of service sector activities. However, in this regard, service activities have been thoroughly investigated to closely monitor the level of financial support, and those activities that are related to the tourism sector have been examined separately, while other activities of the service sector that are, in fact, not related to tourism were separately evaluated. In this regard, all points in Figure 5 represent the sum of points with financial support from businesses over the period from 2011-2016.

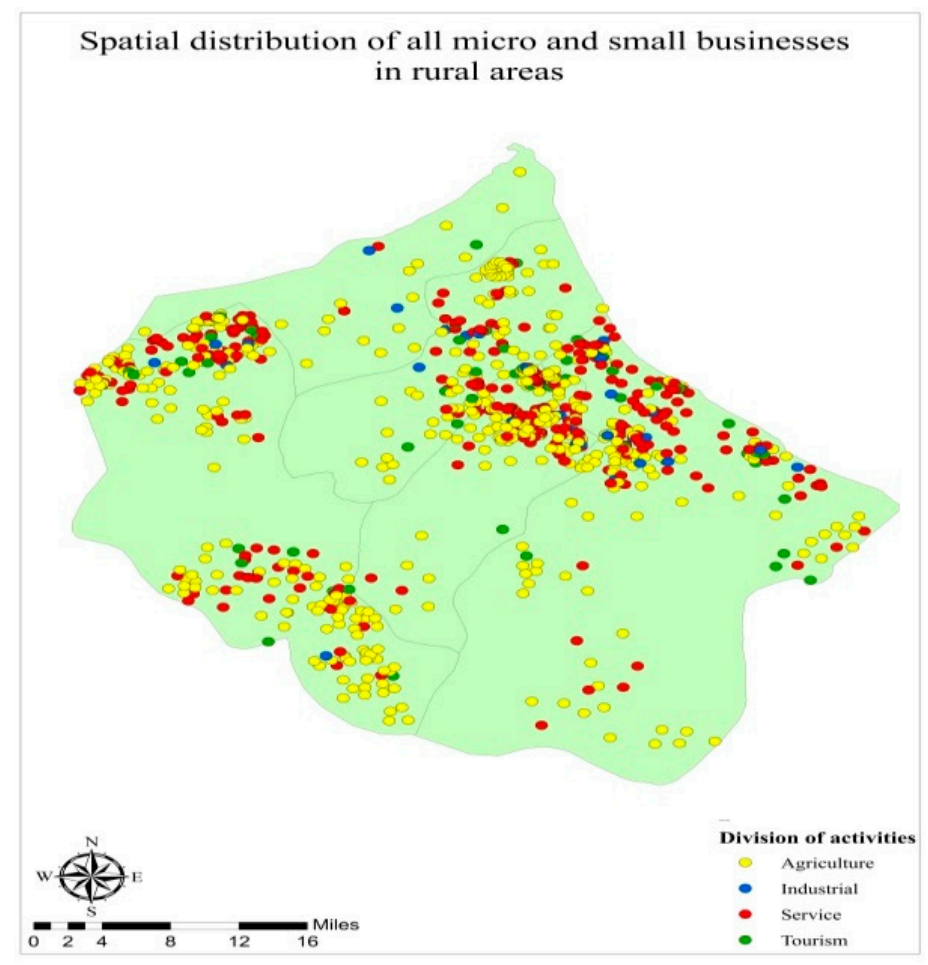

Figure 5. Spatial distribution of all micro and small businesses in industry, service, agriculture and tourism sectors.

In the following, as the research findings show (Table 2), micro and small businesses in the industrial and tourism sectors have the lowest financial support, respectively, and the agricultural and service sectors have respectively the highest financial support. It is worth noting that industrial 
activities, due to the environmental conditions of the region, which have a very high natural potential, such as massive forests, are not due to wide environmental pollution of this region. However, a very important point is related to businesses associated with the tourism sector; in fact, the amount of financial support provided was very small compared to the agricultural sector, in other words, it has undergone a sinusoidal process from 2011-2016, and it cannot be said that each year, the amount of sponsorship of businesses related to the tourism sector is higher than the previous years.

Additionally, the amount of financial support for any tourism business represents a very small amount of support; although this amount was sometimes useful for launching these types of businesses, it was not enough to expand them. In addition, the amount of financial support provided indicates the lack of programs for incremental and financial support during the period, because it has not been able to increase the support process over time and thus shows the orientation and periodical attention in this section during the years mentioned.

Table 2. Total financial support from micro and small businesses in most of the four activities from 2011-2016.

\begin{tabular}{cccccccc}
\hline Business Type & 2011 Million Toman & $\mathbf{2 0 1 2}$ & $\mathbf{2 0 1 3}$ & $\mathbf{2 0 1 4}$ & $\mathbf{2 0 1 5}$ & $\mathbf{2 0 1 6}$ & $\mathbf{2 0 1 7}$ \\
\hline Industrial & 69 & 30 & 43 & 150 & 177 & 142 & 611 \\
Agricultural & 923 & 731 & 877 & 640 & 946 & 1495 & 5612 \\
Service & 769 & 520 & 422 & 461 & 709 & 568 & 3449 \\
Tourism & 202 & 125 & 117 & 151 & 298 & 220 & 1113 \\
Total & 1963 & 1406 & 1459 & 1402 & 2130 & 2425 & 10,758 \\
\hline
\end{tabular}

Measuring the spatial distribution pattern of small businesses related to tourism in mountainous and non-mountainous regions:

In this regard, the elevation layer of the area was first used to identify mountainous and non-mountainous areas as shown in Figure 6. In relation to tourism-related businesses in mountainous and hill areas only, the results showed that in the interval between 2011 and 2016, a total of 23 businesses were formed. This distribution was spatially and totally scattered at the level of the studied regions and did not have an increasing trend during these years, but had a decreasing trend in such a way that in 2011, seven businesses were formed in relation to this sector.

However, during the years 2012-2016, the trend was drastically decreasing, and in the year 2016, it decreased to four businesses. Furthermore, for businesses related to the tourism sector in the plains and valleys, the results showed that from 2011-2016 58 businesses were created, which, compared with the mountainous areas, had a large number of tourism-related businesses. In all the aforementioned years except in 2014, businesses in plains and valleys have been formed at a rate almost twice as high and, in some years, more than twice as high when compared to mountainous and hill areas. In any case, these areas had a decreasing trend over time in such a way that 12 businesses were created in 2011 and eight businesses in 2016.

It should be noted that the tourism businesses in both mountainous and non-mountainous regions are mainly in the form of service businesses and restaurants, and there has been a little emphasis on the use of environmental abilities and products such as the supply of local handicrafts, the sale of local products, the existence of local offices to guide tourists and so on. In fact, it can be said that in most of the villages, tourism-related businesses cannot be found, and only in some villages, they can be found in a point-wise form. For example, in one village, we can rarely find tourism-related businesses that have performed specialized work and activities in this field. Based on these data, tourism is not one of the important and necessary activities for earning money and rural development for the villagers of these areas (Figure 6).

Furthermore, regarding the amount of financial support for tourism-related businesses in the two mountainous and hill areas as compared with valley and plain areas, the results show that the amount of financial support provided in the plains and valleys is almost twice as high as mountainous regions. 
In total, during the mentioned period, 1113 million tomans of financial support were provided for the total of these businesses, in which the share of plain-valley areas was higher than mountainous regions. It seems that the factor of distance has been effective, because due to the remoteness of mountainous areas from the urban areas and the difficulty of access, less businesses have been formed. The importance of the factor of distance will be discussed in (Table 3).

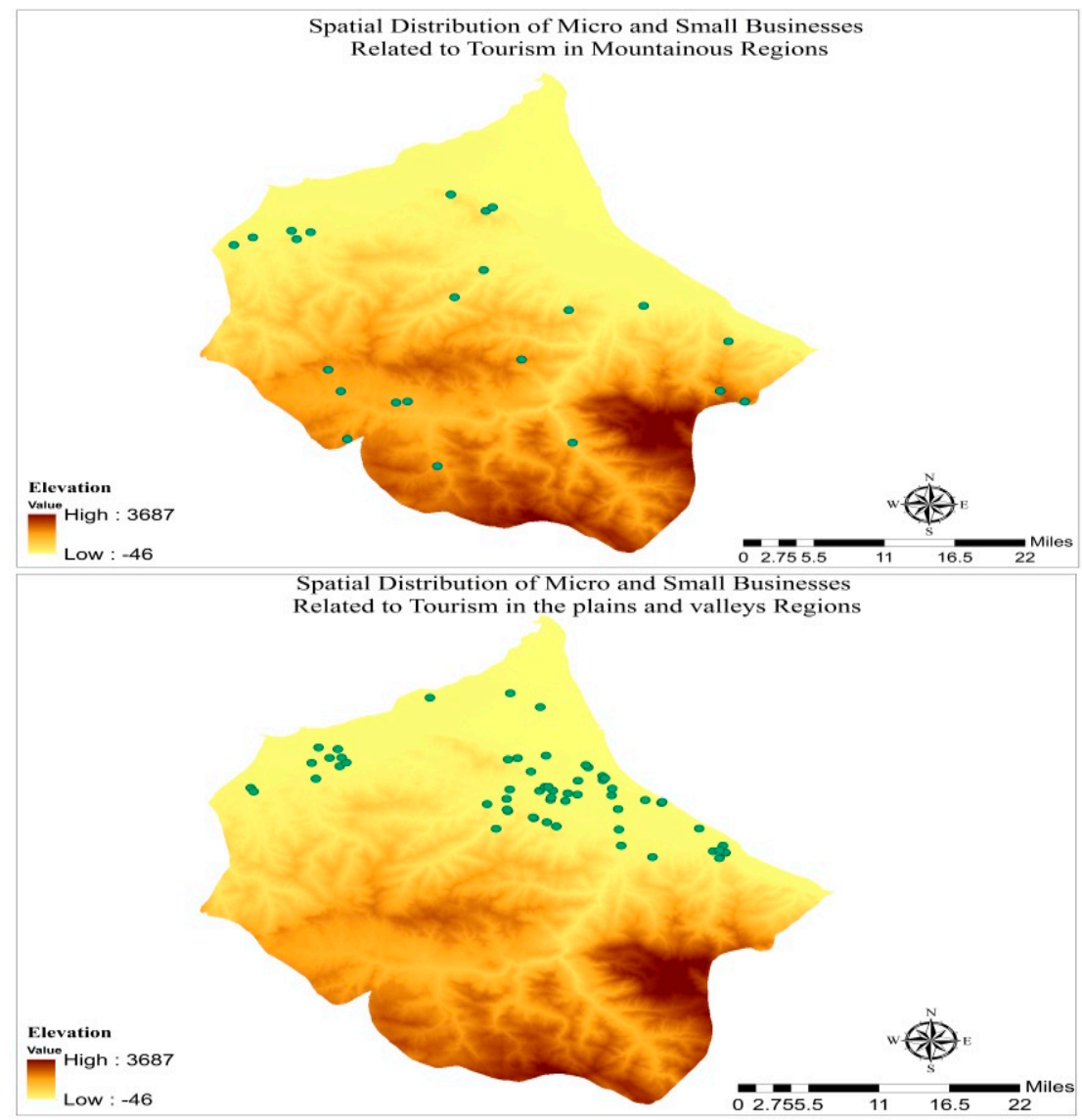

Figure 6. Comparison of the distribution of tourism-related businesses in mountainous and non-mountainous regions.

Table 3. Assessing the status of financial support for tourism-related businesses in mountainous and non-mountainous regions.

\begin{tabular}{cccccccc}
\hline Tourism-Related Businesses & 2011 Million Toman & $\mathbf{2 0 1 2}$ & $\mathbf{2 0 1 3}$ & $\mathbf{2 0 1 4}$ & $\mathbf{2 0 1 5}$ & $\mathbf{2 0 1 6}$ & Total \\
\hline Plains and valleys & 112 & 140 & 80 & 75 & 203 & 145 & 755 \\
Hills and mountains & 70 & 20 & 27 & 76 & 115 & 50 & 358 \\
Total & 182 & 160 & 107 & 151 & 318 & 195 & 1113 \\
\hline
\end{tabular}

Analysis of spatial distribution of tourism businesses in rural areas in terms of remoteness and proximity to urban areas:

As noted earlier, given that the distribution of tourism-related businesses failed to form a distributional pattern, it was attempted to understand whether the remoteness or proximity to urban areas has affected the distribution of tourism businesses in rural areas. To better understand this, the factor of distance was exploited using the Multiple Ring Buffer, and two issues were considered. First, the distance was determined as close to reality as possible in order to express the remoteness or proximity to urban areas for implementation of buffers. The distance of $4 \mathrm{~km}$ from the city was considered the initial distance of the nearest villages from the cities, because higher proximity to urban 
areas is expressed as the suburbs. Second, to enable all the tourism businesses in the region to be placed within the division, the buffer continued up to a distance of $28 \mathrm{~km}$ from the city center to accommodate all tourism businesses in the rural areas (Figure 7).

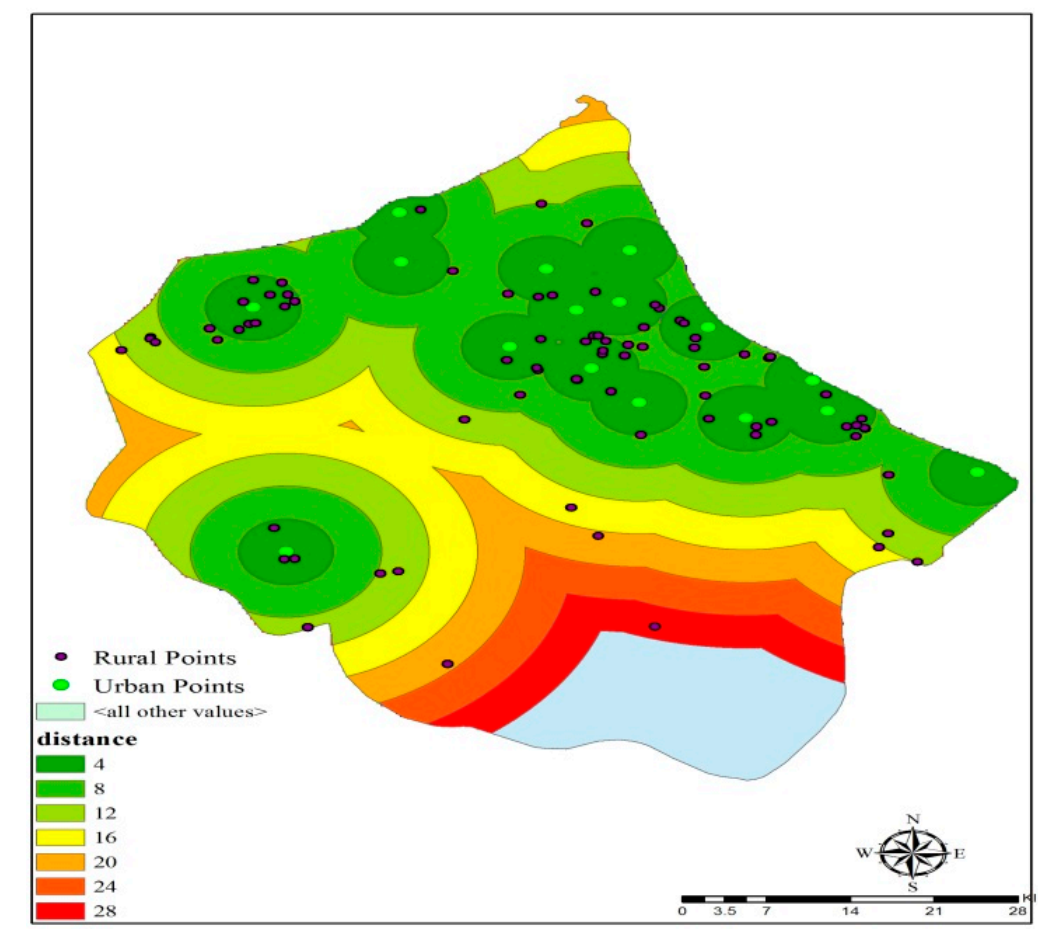

Figure 7. Spatial distribution of tourism businesses in terms of remoteness and proximity to urban areas.

As shown in Figure 7, rural businesses are distributed around the urban areas. Then, we examined whether, in Figure 7, there is a correlation between the distribution of tourism business in rural areas, and remoteness and proximity to urban areas. After converting the mentioned map from polygon to raster, the descriptive data table was used, which shows the number of villages with tourism business in each group of buffers divided by distance $(\mathrm{km})$ (Table 4$)$.

Table 4. Distribution of businesses in terms of the factor of distance from the city in rural areas.

\begin{tabular}{cc}
\hline Distances $\mathbf{( k m )}$ & Number of Tourism-Related Businesses Distributed in the Village \\
\hline 4 & 49 \\
8 & 15 \\
12 & 10 \\
16 & 3 \\
20 & 2 \\
24 & 0 \\
28 & 1 \\
\hline
\end{tabular}

In the following figure, as the correlation results show, the distribution of tourism businesses has reduced in villages located at $4 \mathrm{~km}$ distance from the urban areas. 49 tourism businesses have been formed, which is the largest amount, however, the larger distance between villages and the city center has led to a reduced number of tourism businesses in those villages (Figure 8). 


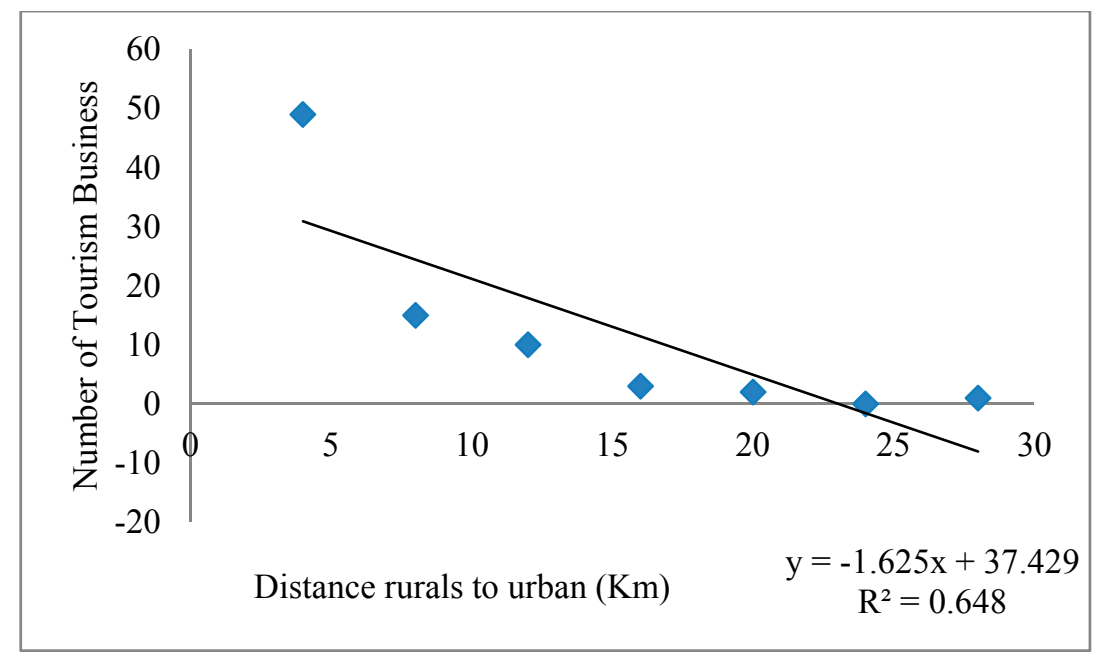

Figure 8. The correlation between distance from urban areas and distribution of tourism business in rural areas.

Analysis of the spatial distribution of all micro and small businesses based on the natural situation: The natural situation of the study area includes four districts: plain and valley-forest located in the plain and valley-mountainous and hills and forests located in the mountains and the hills. According to the classification of the Iranian Statistics Center, the distribution of the businesses from 2011-2016 in these natural situations was investigated to determine the share of each region in setting up businesses. The study evaluates the tendency and willingness of people to set up a business in the four regions. The results showed that the plains and valleys alone have accounted for $54.67 \%$ of businesses, while the forest areas in the plain and valley accounted for $10.02 \%$ of businesses; in total, plains and valleys in the forest and non-forest areas accounted for $64.69 \%$ of businesses. In contrast, there were $22.82 \%$ for mountainous and hill areas and $12.47 \%$ for forest areas located in mountains and hills; in total, the mountainous and hill areas in the forest and non-forest areas accounted for $35.29 \%$ of the businesses. As the results show, the distribution of businesses is quite different in the natural zones mentioned, and the forest areas in both zones have the least amount of business. Factors such as local people's emphasis on livestock farming due to the presence of large pastures and grasslands and, the prevention of forest land use change for the establishment of businesses by government agencies have sometimes led to difficulties in creating businesses related to different sectors, in this case, tourism, in these areas (Table 5).

Table 5. Assessment of the spatial distribution of all businesses in terms of the natural situation of the region.

\begin{tabular}{cc}
\hline Natural Situation & Number of Businesses by $\%$ \\
\hline Plains and valleys & 54.67 \\
Forest in the plain and valley & 10.02 \\
Mountainous and hill & 22.82 \\
Forest in the mountains and hills & 12.47 \\
\hline
\end{tabular}

We also investigated how the distribution of four types of economic activities (agriculture, services, industry and tourism) has been addressed within each of the natural situations. In this regard, the results showed that in the plains and valleys, agricultural activity with $46.41 \%$ was the dominant business in this region, and in contrast, the industrial sector with $4.07 \%$ had the least amount of activities, with only $10.59 \%$ in relation to tourism. In the forest areas located in the plain and valley, the results showed that $55.55 \%$ of the businesses were of the agricultural group, and only $10 \%$ of the 
activities were related to the tourism sector. In the hill and mountainous areas, the results showed that $69.26 \%, 1.95 \%$ and $5.36 \%$ of businesses were related to the agriculture group, industrial sector and tourism-related activities, respectively. Finally, in the forest areas in the mountains and hills, the results showed that $75 \%, 0.85 \%$ and $4.11 \%$ of the activities were in the agricultural, industrial and tourism-related sectors, respectively (Figure 9).
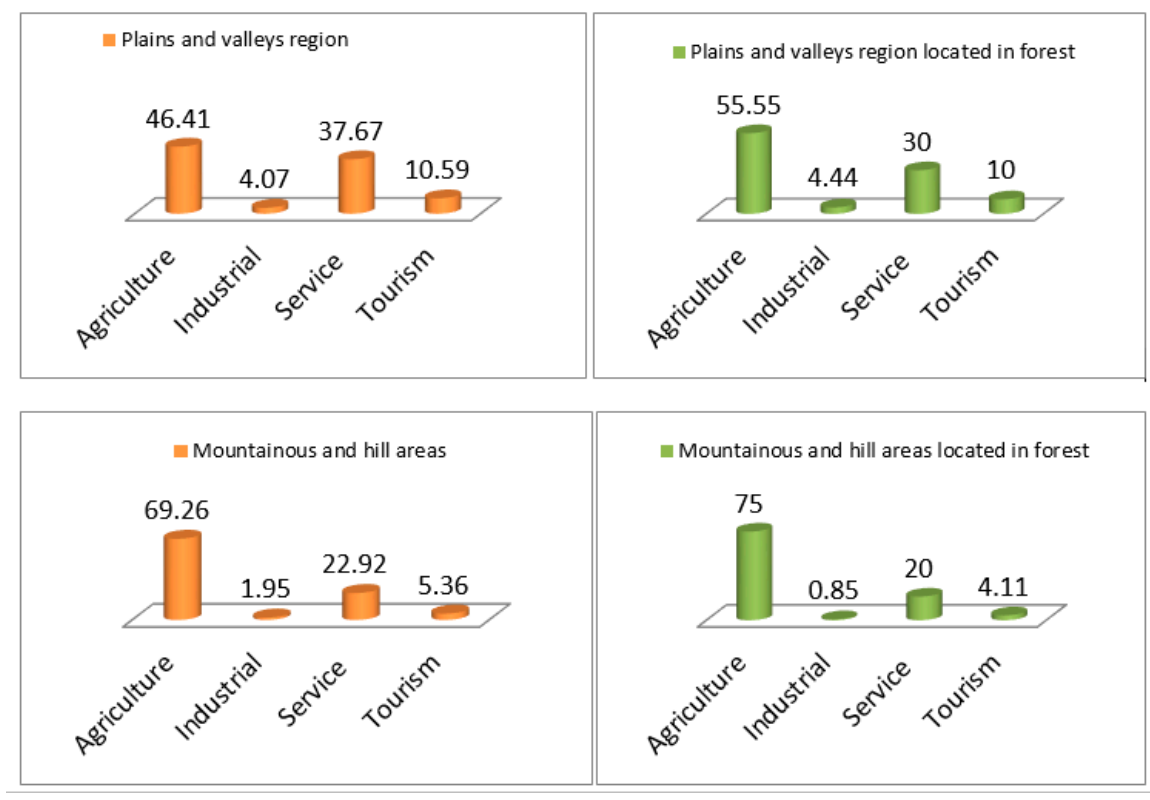

Figure 9. Distribution of economic activities in the four natural conditions of the study area.

\section{Conclusions}

In relation to the spatial distribution of businesses in various economic sectors (agriculture, industry, services and tourism), the results showed that most of the businesses launched from 2011 to 2016 faced an imbalance in various economic sectors because the process of business development must be increased over time. However, it had a sinusoidal and sometimes descending trend, and this distribution is not proportional to the population of the regions.

In the tourism sector, this distribution was quite scattered and pointwise, and so it could not operate centrally and in a clustered manner. As it was not effective in creating a tourist hub, this has led to a declining trend in the tourism sector. In other words, due to the lack of expansion of tourism businesses, this sector has not been able to form any aggregate and clustered pattern. Thus, as mentioned above, it has not been effective in improving the lives of the villagers and has not been able to bring most of the local people into these businesses.

It should also be noted that given that the government can play a facilitating role during the startup of a business, in addition, the role of the government can aid in providing basic facilities and educating local people on the benefits of engaging in a tourism business. Thus, with added education and training as well as funding for businesses, more indigenous people should start tourism businesses, thereby resulting in a growing tourism trade in their small communities.

In conjunction with growth in tourism businesses, rural communities can capitalize on their existing assets, such as agriculture and small services. Coordinated tourism planning efforts which use existing products to create tourism businesses, such as farm tourism, u-picks, educational or interpretive farms, experiential farms are all critical to keeping the balance of existing businesses in line with new product development. Therefore, it should finally be pointed out that the share of each economic activity will be determined through the spatial distribution methods in the study area from the point of view of the authorities. In this regard, tourism can be considered a very important source 
of income in the life cycle of villagers by balancing the distribution of businesses, especially through public sector support and by providing advice and awareness to local people.

In this way, one-dimensional emphasis on the agricultural sector will definitely lead to long-term environmental degradation as a result of excessive use. Thus, educating locals to the benefits of combining their farms with hosting visitors, revenue for the individuals can be increased and diversified. In the case of the provision of necessary infrastructure and conditions, the ability of the local people and the region to attract tourists will be increased, and the business space can hopefully replace the unemployment in the region.

Regarding the importance of the factor of distance (proximity to urban areas), the results showed that the proximity of villages to cities was very important for the establishment of tourism businesses, because most of the businesses in this area were formed in villages near urban areas. This finding is consistent with tourism planning and development literature, which shows that access is a critical factor for tourism competitiveness [69].

It seems that the lack of attention to remote areas, the lack of provision of facilities, and the lack of advisory services and information about environmental potential in these businesses has prevented these types of businesses from forming in remote villages, or has led to random and wholly dispersed occurrences of these businesses. Therefore, familiarizing people with distant places and providing incentives to enter the tourism business is essential. Providing support for these businesses is critical and having the government indicate a rural area that they will invest in for tourism growth should all result in a more diversified economy and greater economic stability for villagers.

Over time, with a focus on the set of tourism businesses in each village, tourism benefits can be achieved, especially in the field of rural development. In this way, it has not only benefited all the villagers, but has also provided a service and welfare field for the incoming tourists due to a variety of facilities and services. It also makes them familiar and satisfied with the region, creates incentive to return, and promotes the tourism facilities for other tourists.

Author Contributions: The present article is extracted from the doctoral dissertation of Mehdi Hajilo guided by Mojtaba Ghadiri Masoom and advised by Seyed Hassan Motiee Langroudi, Hassanali Faraji Sabokbar and Lori Pennington-Gray, sponsored by the Fund for Support of Researchers and Technologists of the country.

Conflicts of Interest: The authors declare no conflicts of interest.

\section{References}

1. Liu, H.S.; Chih, F.; Chou, S. Tourism strategy development and facilitation of integrative processes among brand equity, marketing and motivation. Tour. Manag. 2016, 54, 298-308. [CrossRef]

2. Nunkoo, R.; Gursoy, D. Residents' support for tourism: An identity perspective. Ann. Tour. Res. 2012, 39, 243-268. [CrossRef]

3. Ghadiri Masoom, M.; Stelaji, A.; Pazoki, M. Sustainable Tourism; Tehran University Press: Tehran, Iran, 2010.

4. Teyu, H. Rural Tourism in Taiwan: Motivation. Expectations and Satisfaction. Ph.D. Thesis, University of the Incarnate Word, Hong Kong, China, 2014.

5. Sharpley, R. Rural Tourism and the Challenged of Tourism Diversification: The Case of Cyprus. Tour. Manag. 2002, 23, 233-344. [CrossRef]

6. Bala Banki, M.; Ismail, N. Hairul Understanding the characteristics of family owned tourism micro businesses in mountain destinations in developing countries: Evidence from Nigeria. Tour. Manag. Perspect. 2015, 13, 18-32. [CrossRef]

7. Kiakojori, D.N.L.; Akhundzadeh, T. The Impact of Tourism on the Development of Entrepreneurship and Employment, National Conference on Entrepreneurship University (Knowledge-Based Industry); Mazandaran University: Babolsar, Iran, 2013.

8. Dadvarkhani, F.; Rezvani, M.R.; Imeni Ghashlagh, S.; Bouzar Jomhari, K. Analysis of the role of tourism in the development of entrepreneurial characteristics and entrepreneurial orientation among rural youth (Case study: Kandovan and Skandan villages, City of Osko). Hum. Geogr. Res. 2011, 78, 169-195. 
9. Haji Mohammad Amini, S.; Tullayi, S.; Farjam, R. Identification and Analysis of Tourism Cluster in the City of Shiraz Using Extended Porter Model. Reg. Plan. Q. 2011, 1, 1-16.

10. Stewart., B.; Skinner, J. Cluster Theory and Competitive Advantage: The Torquay Surfing Experience; Griffith University: Brisbane, Australia, 2005.

11. Miller, M. Cluster-Based Development in the Tourism Industry: Putting Practice into Theory. Appl. Res. Econ. Dev. 2005, 2, 47-63.

12. Huybers, T.; Bennett, J. Environmental Management and the Competitiveness of Nature-Based Tourism Destinations. Environ. Resour. Econ. 2003, 24, 213-233. [CrossRef]

13. Rosenfield, S.A. Just Clusters, Economic Development Strategies that Reach More People and Place; Regional Technology Strategies Inc.: Carrboro, NC, USA, 2002.

14. Culture of the Villages of Rudsar City. Planning Deputy of Gilan Governorate 7510; Culture of the Villages of Rudsar City: Rasht, Iran, 2007.

15. Keshvardoust, A. Gilanshahr; Varasteh Publication: Rasht, Iran, 2006.

16. Management and Planning Organization of Gilan Province. Basic Statistics of Gilan Province. 2006. Available online: http:/ / mpogl.ir / (accessed on 3 December 2017). (In persian)

17. Molaei Hashtjin, N.; Ebrahimi, H. Identification of Tourism Abilities and Attractions and Its Impact on Tourism Attraction in the City of Amlash. Reg. Plan. Q. 2014, 4, 95-108.

18. Goodarzvand Chegini, M.; Mola Hashin, N. An Analysis of the Strategies for the Development of Tourism Industry in Guilan Province. Geogr. Outlook Q. 2009, 4, 179-192.

19. Randelli, F.; Romei, P.; Tortora, M. An evolutionary approach to the study of rural tourism: The case of Tuscany. Land Use Policy 2014, 38, 276-281. [CrossRef]

20. Rezvani, M.; Naser, B. Analyzing the status of rural tourism in country's macro-economic programs (with emphasis on five-year national development plans). J. Plan. Dev. Tour. 2014, 3, 11-30.

21. WTTC. The Authority on World Travel E Tourism Economic Impact of Travel E Tourism Annual Update: Summary; WTTC: London, UK, 2013.

22. Talebi, H.; Modiri, M.; Tarhani, F. Prioritizing the components of tourism development in Iran with the approach of fuzzy multi criteria decision making: Case study Iran Cultural Heritage, Handcraft and Tourism Organization. J. Plan. Dev. Tour. 2017, 6, 94-114.

23. Ayyagari, M.; Beck, T.; Demirguc-Kunt, A. Small and medium enterprises across the globe. Small Bus. Econ. 2007, 29, 415-434. [CrossRef]

24. Bengtson, A.; Pahlberg, C.; Pourmand, F. Small firms' interaction with political organizations in the European Union. Ind. Mark. Manag. 2009, 38, 687-697. [CrossRef]

25. Morris, R.; Brennan, G. Creating a seamless local government and small business interface for better regional economic development outcomes. Presented at the ICSB World Conference, Brisbane, Australia, 7-10 June 2000.

26. Akbaba, A. Understanding Small Tourism Businesses: A Perspective from Turkey. J. Hosp. Tour. Manag. 2012, 19, 31-47. [CrossRef]

27. Morrison, A.; Carlsen, J.; Weber, P. Small tourism business research change and evolution. Int. J. Tour. Res. 2010, 12, 738-749. [CrossRef]

28. Peltonen, A.; Komppula, R.; Ryhänen, H. Overview of SMEs in Tourism, Finland. In SMEs in Tourism: An International Overview; Morrison, A., Thomas, R., Eds.; Atlas: Arnhem, The Netherlands, 2004; pp. 25-33.

29. Mclennan, C.L.J.; Becken, S.; Watt, M. Learning through a cluster approach: Lessons from the implementation of six Australian tourism business sustainability programs. J. Clean. Prod. 2016, 111, 348-357. [CrossRef]

30. Antunes, P.; Mourao, H. Resilient business process management: Framework and services. Expert Syst. Appl. 2011, 38, 1241-1254. [CrossRef]

31. Sahebjamnia, N.; Torabi, S.A.; Mansouri, S.A. Integrated business continuity and disaster recovery planning:Towards organizational resilience. Eur. J. Oper. Res. 2015, 242, 261-273. [CrossRef]

32. Chen, C.S.; Elston, A.J. Entrepreneurial motives and characteristics: An analysis of small restaurant owners. Int. J. Hosp. Manag. 2013, 35, 294-305. [CrossRef]

33. Jaafar, M.; Abdul-Aziz, A.R.; Maideen, S.A.; Mohd, S.Z. Entrepreneurship in the tourism industry: Issues in developing countries. Int. J. Hosp. Manag. 2011, 30, 827-835. [CrossRef] 
34. Barati, J.; Rasoulzadeh, M.; Rafiee Darani, H.; Mazhari, M. Strategic Management in the Business Environment of Urban Economics (Case Study: Religious Tourism of the Holy City of Mashhad). J. Urban Econ. Manag. 2014, 6, 109-125.

35. Simeon, N.S.; Goldmark, L. Small Firm Growth in Developing Countries. World Dev. 2009, 37, 1453-1464.

36. Sa'di, H. Economic Evaluation of Small Businesses of Rural Women (Case Study: Hamedan Province). J. Agric. Econ. 2013, 7, 41-58.

37. Dadvarkhani, F. Rural Development and Women's Challenges. Geogr. Res. 2006, 55, 171-181.

38. Mohapatra, S.; Rozelle, S.; Goodhue, R. The Rise of Self-Employment in Rural China: Development or Distress. World Dev. 2007, 35, 163-181. [CrossRef]

39. US. Small Business Administration (SBA). Available online: http://www.sba.gov/ (accessed on 1 January 2012).

40. Kalantari, K. Unequal Regional Small Industries and the Experience of Developing Countries. Jihad Mon. 1996, 188-189, 57-62.

41. Ale Ebrahim, N.; Ahmed, S.; Taha, Z. Virtual R\&D teams and SMEs growth: A comparative study between Iranian and Malaysian SMEs. Afr. J. Bus. Manag. 2010, 4, 2368-2379.

42. Varmazyari, H.; Imani, B. Analysis of the Resiliency of Rural Businesses in the City of Malekan. J. Entrep. Dev. 2017, 10, 181-200.

43. Bosworth, G. Characterising Rural Businesses E Tales From The Paperman. J. Rural Stud. 2012, 28, 499-506. [CrossRef]

44. Ali Mirzaii, E.; Asadi, A.; Tahmasbi, M. Barriers to Development of Small and Medium-sized Enterprises of Rural Entrepreneur in Khuzestan Province (Case Study: Date Supplementary Industries). J. Entrep. Dev. 2011, 3, 165-184.

45. Porter, M. Clusters and the New Economics of Competition; Harvard Buisness Rewiew: Boston, MA, USA, 1998.

46. Vellas, F. Economie et Politique du Tourisme International; Economica: Paris, France, 2002.

47. Soukiazis, E.; Proença, S. Tourism as an alternative source of regional growth in Portugal: A panel data analysis at NUTS II and III levels. Port. Econ. J. 2008, 7, 43-61. [CrossRef]

48. Ólafsdóttir, R.; Runnström, M.C. A GIS approach to evaluating ecological sensitivity for tourism development in fragile environments. A case study from SE Iceland. Scand. J. Hosp. Tour. 2009, 9, 22-38. [CrossRef]

49. Andriotis, K. Researching the development gap between the hinterland and the coast-Evidence from the island of Crete. Tour. Manag. 2006, 27, 629-639. [CrossRef]

50. Irvine, W.; Anderson, A.R. Small tourist firms in rural areas: Agility, vulnerability and survival in the face of crisis. Int. J. Entrep. Behav. Res. 2003, 10, 229-246. [CrossRef]

51. Pearce, D.G. Tourism Today: A Geographical Analysis; Longman Scientifical and Technical: London, UK, 1995.

52. Dolores Sarrión-Gavilán, M.; Dolores Benítez-Márquez, M.; Mora-Rangel, E.O. Spatial distribution of tourism supply in Andalusia. Tour. Manag. Perspect. 2015, 15, 29-45. [CrossRef]

53. Nasiri, M. The role of government in the spatial development of the city of Babol. J. Geogr. Res. 2004, 48, 31-48.

54. Hedayat, M. Characteristics of the physical space and residential texture of Isfahan city. Q. J. Geogr. Res. 2001, 60, 111-129.

55. Aliyu, A.; Shahidah, M.A.; Aliyu, R.M. Mapping and Spatial Distribution of Post Primary Schools in Yola North Local Government Area of Adamawa State, Nigeria. Int. J. Sci. Technol. 2013, 2, 405-422.

56. Keramati, Z.; Izadi, H.; Soltani, A.; Lotfi, S. Spatial Distribution Analysis and Accessibility to Urban Gardens (Case Study: City of Shiraz). Urban Plan. Geogr. Res. 2015, 3, 531-588.

57. Alijani, B. Spatial Analysis. J. Spat. Anal. Environ. Hazards 2015, 2, 1-14.

58. Li, L. A review of entrepreneurship research published in the hospitality and tourism management journals. Tour. Manag. 2008, 29, 1013-1022. [CrossRef]

59. Thomas, R.; Shaw, G.; Page, S.J. Understanding small firms in tourism: A perspective on research trends and challenges. Tour. Manag. 2011, 32, 963-976. [CrossRef]

60. Karami Benmaran, Z.; Khosravi Pour, B.; Ghanian, M.; Baradaran, M. Identification of factors affecting the formation of small and medium enterprises with a focus on rural tourism (Case study: Kan District, Tehran). Rural Res. 2014, 5, 737-758.

61. Yasori, M.; Vatankhah Kalvarzi, Z. The role of tourism in the development of rural women's entrepreneurship (Gurab district in the city of Fouman). Geogr. Stud. Arid Reg. 2015, 5, 46-59. 
62. Elena, C.; Tatiana, S. Event tourism in Russian region: Opportunity for small-scale business growth. Procedia Econ. Financ. 2015, 26, 183-187. [CrossRef]

63. Farahmand, S.; Khosh Akhlaq, R.; Pahlavanzadeh, B. Analysis of Factors Affecting the Distribution of Economic Activities in the City of Isfahan. Q. J. Econ. Res. 2013, 13, 133-153.

64. Zangi Abadi, A.; Pour Eidivand, L.; Heidaripour, E.; Moslehi, M. Spatial Analysis of Tourism Development Indicators Using TOPSIS Model Case Study: Cities of Isfahan Province. Geogr. Urban Dev. Mag. 2012, 1, 51-73.

65. Fong, E.; Luk, C.; Ooka, E. Spatial distribution of suburban ethnic businesses. Soc. Sci. Res. 2005, 34, $215-235$. [CrossRef]

66. Abomeh, O.; Nuga, O.; Blessing, I. Utilization of GIS technology for tourism management in Victoria island Lagos. Eur. Sci. J. 2013, 9, 1857-7881.

67. Dye, A.S.; Shaw, S.L. A GIS-based spatial decision support system for tourists of Great Smoky Mountains National Park. J. Retail. Consum. Serv. 2007, 14, 269-278. [CrossRef]

68. Ali, A. Spatial Statistical Analysis with ArcGIS, 1st ed.; Tehran Municipality's Information and Communication Technology Organization: Hafez Ave, Tehran, 2011.

69. Crouch, G.I.; Ritchie, J.B. Tourism, competitiveness, and societal prosperity. J. Bus. Res. 1999, 44, $137-152$. [CrossRef]

(C) 2017 by the authors. Licensee MDPI, Basel, Switzerland. This article is an open access article distributed under the terms and conditions of the Creative Commons Attribution (CC BY) license (http:/ / creativecommons.org/licenses/by/4.0/). 